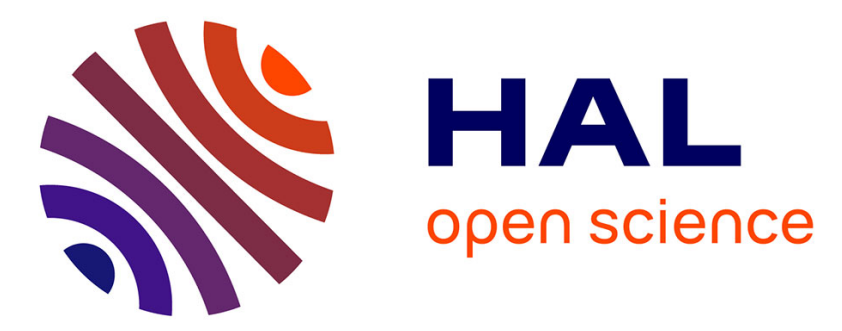

\title{
Adherence to antiretroviral treatment in patients with HIV in the UK: a study of complexity - AID IMPACT SPECIAL ISSUE
}

Richard Harding

\section{- To cite this version:}

Richard Harding. Adherence to antiretroviral treatment in patients with HIV in the UK: a study of complexity - AID IMPACT SPECIAL ISSUE. AIDS Care, 2008, 20 (04), pp.442-448. 10.1080/09540120701867032 . hal-00513446

\section{HAL Id: hal-00513446 \\ https://hal.science/hal-00513446}

Submitted on 1 Sep 2010

HAL is a multi-disciplinary open access archive for the deposit and dissemination of scientific research documents, whether they are published or not. The documents may come from teaching and research institutions in France or abroad, or from public or private research centers.
L'archive ouverte pluridisciplinaire HAL, est destinée au dépôt et à la diffusion de documents scientifiques de niveau recherche, publiés ou non, émanant des établissements d'enseignement et de recherche français ou étrangers, des laboratoires publics ou privés. 

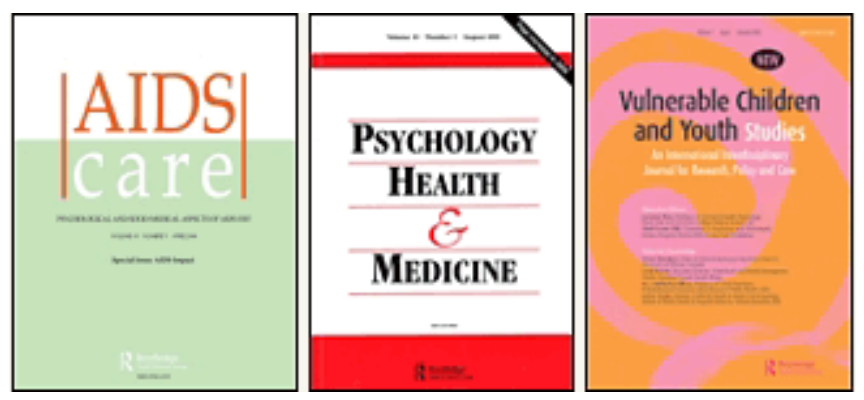

\section{Adherence to antiretroviral treatment in patients with HIV in the UK: a study of complexity - AID IMPACT SPECIAL} ISSUE

\begin{tabular}{|r|l|}
\hline Journal: & $\begin{array}{l}\text { AIDS Care - Psychology, Health \& Medicine - Vulnerable Children } \\
\text { and Youth Studies }\end{array}$ \\
\hline Manuscript ID: & AC-2007-07-0323.R1 \\
\hline Journal Selection: & AIDS Care \\
\hline Keywords: & adherence, antiretroviral therapy, timing \\
\hline \multicolumn{2}{|r}{} \\
\hline
\end{tabular}

\section{今 scholarONE" \\ Manuscript Central}




\section{Adherence to antiretroviral treatment in patients with HIV in the UK: a study of complexity.}

Sherr, L; Lampe F; Norwood, S; Leake-Date, H; M Johnson, G Arthur, M Fisher, J Anderson, S Zetler, S Edwards, Harding, R

Lorraine Sherr (correspondence author)

Dept of Primary Care and Population Sciences

Royal Free University College Medical School

PCPS, Rowland Hill St, London NW3 2PF UK

Tel 442077940500

Fax 442077941224

Email : L.sherr@pcps.ucl.ac.uk

Fiona Lampe

Dept of Primary Care and Population Sciences

Royal Free University College Medical School

Sally Norwood

Dept of Primary Care and Population Sciences

Royal Free University College Medical School

Heather Leake Date

Brighton \& Sussex University Hospitals NHS Trust

Richard Harding

Department of Palliative Care, Policy and Rehabilitation

King's College London School of Medicine

Margaret Johnson

Royal Free Hospital

Simon Edwards

Mortimer Market

Martin Fisher

Brighton and Hove

Gilly Arthur

Archway Sexual Health Clinic

Sarah Zetler

Homerton University Hospital NHS Trust

Jane Anderson

Homerton University Hospital NHS Foundation Trust 


\title{
Adherence to antiretroviral treatment in patients with HIV in the UK: a study of complexity.
}

\begin{abstract}
Adherence to HIV treatment regimes is a core element to viral suppression. Yet measurement of adherence is complex. Although adherence levels are good predictors of outcome, they do not always provide full explanations of observed variations in responses. This study was set up to examine the complexity of adherence measurement and to examine rates of adherence in the presence of complex measurement. 502 consecutive attenders at HIV clinics in the UK $(80.5 \%$ response rate), provided detailed measurement on adherence in the preceding 7 days, setting out dose adherence, as well as measures of timing and dietary conditions. In addition, a range of psychological, demographic and relationship data were gathered to understand predictors of full and partial adherence. Although 79.1\% reported dose adherence in the previous 7 days, $42.8 \%$ had not taken the dose at the correct time, and $27.2 \%$ had not taken the dose under the correct circumstances. Using a more complex composite measure of full adherence, rates reduced from $79.1 \%$ to $41.5 \%$. Comparisons of those deemed fully adherent, partially adherent and non adherent were carried out. Fully adherent significantly more likely to be older $(\mathrm{F}=7.8$, $p<0.001)$, UK born $(\mathrm{F}=6.8, p=0.03)$, code ethnicity as white $(\mathrm{F}=5.3, p=0.07)$, record higher quality of life $\left(\mathrm{X}^{2}=8.7, p=0.01\right)$, lower psychological symptoms $\left(\mathrm{X}^{2}=15.2\right.$, $p=0.001)$ and lower global distress symptoms $\left(\mathrm{X}^{2}=6.9, p=0.03\right)$. There were no differences according to education, behavioural and attitudinal variables (disclosure, stable relationship, STI diagnosed, number of sexual partners, unprotected sex, optimism or treatment switching). Fully adherent groups were significantly more likely to be in agreement with their doctor on treatment initiation $\left(X^{2}=6.2 p=0.045\right)$, satisfied with the amount of involvement in the decision making process $\left(\mathrm{X}^{2}=7.3\right.$ $\mathrm{p}=.026)$, their wishes were considered $\left(\mathrm{X}^{2}=12.5 \mathrm{p}=0.002\right)$ monitoring of their condition $\left(\mathrm{X}^{2}=7.1 \mathrm{p}=0.028\right)$. Multivariate analysis showed that variables which contributed significantly at a 5\% criterion level to complex adherence were physical symptoms $(\mathrm{OR}=0.56, \mathrm{p}=0.05)$, psychological symptoms $(\mathrm{OR}=2.37, \mathrm{p}<0.001)$.age $(\mathrm{OR}=0.96, \mathrm{p}=0.02)$, education $(\mathrm{OR}=0.54, \mathrm{p}=0.03)$, having more than one sexual partner $(\mathrm{OR}=0.46, \mathrm{p}=0.03)$, having risky sex $(\mathrm{OR}=4.30, \mathrm{p}=0.002)$, and being optimistic about treatments $(\mathrm{OR}=0.42, \mathrm{p}=0.01)$, The softer markers of adherence are not usually measured in follow up and may account for variations in treatment responses. The complexity of adherence needs to be understood and addressed to maximise treatment efficacy.
\end{abstract}

\section{Acknowledgements}

We wish to acknowledge the contribution of The Clinicians on the Switching team, research assistance from Amanda Jayakody, research nurses at participating clinics, and all survey respondents. This research was assisted with an unrestricted educational grant from GlaxoSmithKline, with input from the Adherence Strategy Group. 


\section{Adherence to antiretroviral treatment in patients with HIV in the UK: a study of complexity.}

\section{Introduction}

Mortality and morbidity associated with HIV infection in the UK have declined exponentially since the introduction of highly active antiretroviral therapy (HAART) (Lundgren et al 2006). To achieve these gains patients and clinicians must engage with complex and demanding long term treatment regimens. These call for consistently high levels of adherence to perform to their maximum potential, maintaining viral suppression. Not only does poor adherence put the efficacy of treatment for the patient at risk, it also leads to the emergence of drug resistance. This in turn will compromise future treatment options for the individual and increases the risk of exposing others to drug resistant viral strains.

Non - adherence has been directly associated with treatment failures (Paterson et al 2000), viral rebound and a need for regimen switching. As treatment options are limited, this poses an urgent challenge. For maximum efficacy adherence levels of at least $95 \%$ are required - far higher than has been achieved for most medications that have previously been studied (Haynes et al 2002). Substantial rates of non adherence have been widely described in the literature (Poppa et al 2004) despite a multitude of interventions that have been formulated to support and promote high levels of treatment adherence (Chesney et al 2000).

All interventions to promote or enhance adherence are reliant on accurate and adequate adherence measurement. Such measurement has proved to be problematic.. A number of studies have explored adherence measurement to generate a gold standard for audit and research purposes. Most adherence studies use a selection (or a single indicator) from five forms of measurement including patient self report, doctor report, repeat prescription filling, mechanical devices (such as Medical Event Monitoring System MEMS caps MEMS View 1998) and biological markers which were claimed would measure drug levels directly or indirectly. Some studies describe 
electronic devices as the gold standard, while others use multiple measures to $\log$ adherence. Yet electronic caps can only tell if the container was opened and not whether the compound was ingested. It runs the risk of erroneously counting someone as adherent who opens the bottle but does not take the compound. It also runs the risk of counting someone as non-adherent who removes multiple doses at one time point, takes them all at the correct time, but is only recorded on the single occasion of opening the container.

Attempts to measure adherence, in themselves, do not interfere with levels of adherence (Sherr 2000). Efforts have been made to determine characteristics of patients (van Duleman et al 2007) who are particularly likely to be non-adherent (Simoni et al 2006). Factors that have been found to be associated with adherence levels include mental health problems (Mills et al 2006), preparation, disclosure, coping, attitude to treatment (Horne et al 2004), understanding (Poppa et al 2004) and the quality of the relationship between doctor and patient (Aronson 2007).

Although adherence levels are one predictor of clinical outcome, they do not always explain all the observed variations in response. Liu et al (2006) note that errors in dose timing may be crucial in understanding virological response and that percent of doses taken is insufficient to exclusively explain outcome effects that are monitored in their US samples (Liu et al 2006b). This would suggest that studies examining adherence which simply utilise a recall of dose are insufficient and a more complex measure of adherence, involving dose timing as well as adherence to circumstances of drug administration are important for a complete and accurate measure of adherence.

A closer scrutiny of existing studies reveal few, if any, that explore the detailed circumstances associated with adherence. This cross sectional study based in clinical settings in London and south east England examines the complex array of factors that impinge on adherence, both in terms of dose timing and contextualising this aspect in a broader analysis of patients lives and circumstances. 


\section{Methods}

The study, carried out between 2005 and 2006 utilised a cross sectional, questionnaire based design. Consecutive attendees at four London and one South-eastern UK HIV treatment outpatient clinics who were currently on antiretroviral therapy were eligible for inclusion. Potential participants had to be over 18 years of age, deemed clinically well enough to participate by their doctor, able to speak sufficient English to complete the standardised inventory and give informed consent, and currently taking HIV medication. Participants were requested to complete the questionnaire, return it to a sealed receptacle or post it back directly to the research centre in a pre-paid envelope. A researcher was available to answer queries.

Adherence was sured using patient self report recall over the preceding seven days. Particip were asked to provide detailed information on the number of missed doses over the past 7 days. For the medication taken, they were asked to record how many doses were taken on time (all, most or some) and how many under the correct circumstances such as food or an empty stomach (all, most or some ). Full adherence was coded as no missed doses and all taken at correct time and under correct circumstances. Regimens and compounds that had no time or circumstance/diet requirements were automatically coded only on dose adherence. Partial adherence was coded as those who had taken all doses, but had not been fully adherent to dose timing and/or circumstances (when these were required). Non adherence included all other responses.

All participants then completed a standardised questionnaire to obtain information on:

- Demographics - information on race, ethnicity, residency, time in the UK, sexuality, education and employment was systematically gathered.

- Sexual behaviour. Partnership behaviour was monitored, together with sexual risk behaviour in the preceding 3 months, defined as unprotected sexual intercourse with someone of unknown or discordant HIV status.

- Disclosure of HIV status was recorded based on questionnaires validated in previous studies (Kalichman 2003). 
- Treatment switching was monitored to note first treatment, single or multiple switch experience.

- Symptom and pain levels were monitored using the MSAS inventory (Chang et al 2004). This is a multiple symptom inventory that provides three total measures (Physical, Psychological and Global Pain Index), providing insight into pain and suffering symptoms within the preceding week.

- Quality of life was measured utilising the Euroquol (The Euroquol Group 1990) and study specific ratings on quality of life using a 5 point rating scale (not at all good to very good).

- Satisfaction and attitudes were measured in relation to medical care and treatment optimism using Lickert type rating scales of optimism and elements of doctor-patient care and communication (decision making, information, monitoring, agreement, involvement) rated on a 5 point scale.

Data was analysed using SPSS.pc statistical package. Data was entered into SPSS and analysed to explore consistent differences between those who were fully adherent, partially adherent and non adherent. A binary split was made between those who were fully adherent according to our stricter criteria versus the rest, in order to examine predictors of full adherence. Ethical approval for the study was obtained through the multiple site ethical approval process for each centre. The study received guidance from the Adherence Strategy group, which included multi-agency and multidisciplinary members and particularly patient representation.

\section{RESULTS}

\section{Sample}

During the study period, 1006 patients attended the 5 clinics, of whom 627 were eligible for inclusion, (276 not on treatment, remainder not fitting other inclusion criteria). 502 people with HIV on treatment provided complete data for analysis, representing an $80.06 \%$ response rate. They comprised $22.6 \%$ heterosexual females, 12. $-\frac{\rho}{2}$ eterosexual males and $63.5 \%$ gay males. $67 \%$ reported their ethnicity as "wliw and $33 \%$ as Asian, Black or mixed race. 


\section{Prevalence of non-adherence}

From the 502 patients, $397(79.1 \%)$ missed no dose in the preceding week, 10.6\% missed one dose, $4.4 \%$ missed two doses, and $6 \%$ missed three or more doses. Furthermore, $42.8 \%$ reported that they had not taken their dose according to the correct timing schedule and $27.2 \%$ reported that they had not taken their dose according to the correct food requirements. Figure 1 below sets out missed doses as well as dose timing and circumstance adherence.

\section{Insert figure 1 here}

According to a percent dose adherence model, $79.1 \%$ of the sample would be classified as adherent. However, according to the stricter measure where full adherence is measured including dose adherence and ensuring accurate dose timing and circumstance adherence, this figure falls to $41.5 \%$

\section{Insert figure 2 here}

\section{Full, partial and non adherence.}

Table 1 below sets out comparisons on a range of variables for those who were fully adherent $(41.5 \%)$, those who were partially adherent (36.1\%), and those who reported being non-adherent (22.4\%).

\section{Insert table 1 here}

Quality of life score (Euroqol-VAS) was significantly higher for fully adherent respondents (Mean rank 296.79) compared to partially adherent (258.21) or not adherent respondents (254.52) (Kruskal-Wallis $\mathrm{X}^{2}=8.7, p=0.01$ ). This was true on a range of quality of life measurements - Euroqol-5D (mean rank fully adherent 282.45, partially adherent 247.60 and not adherent 243.99 , Kruskal-Wallis $X^{2}=7.6$, 
$p=0.02$ ) and quality of life at present (mean rank fully adherent 191.78, partially adherent 172.41 and not adherent 140.41, Kruskal-Wallis $\mathrm{X}^{2}=15.2, p=0.001$ ). Psychological and Global symptom burden scores were both significantly higher for non-adherent respondents (Psychological symptoms mean rank fully adherent 255.29, partially adherent 297.06, not adherent 318.50, Kruskal-Wallis $\mathrm{X}^{2}=15.2, p=0.001$; Global distress was significantly lower for fully adherent respondents (index mean rank for fully adherent 265.46, partially adherent 289.60 and not adherent 311.66, Kruskal-Wallis $\mathrm{X}^{2}=6.9, p=0.03$ ). There were no significant differences between the groups according to gender, sexuality, education or employment. However respondents who were UK born were more likely to be fully adherent $(47.5 \%$ vs $37.3 \%)$ and less likely to be non adherent $(17.2 \%$ vs $24.9 \%$ x $2=6.8 \mathrm{p}=.03)$. Length of residency in the UK also differed significantly with those in the UK for 5+ years more likely to be fully adherent ( $44.8 \%$ vs $34.5 \%)$ and less likely to be non adherent $(18.0 \%$ vs $\left.31.0 \% \mathrm{x}^{2}=7.7 \mathrm{p}=.02\right)$.

\section{Insert table 2 here}

There were no differences according to education, behavioural and attitudinal variables (disclosure, stable relationship, STI diagnosed, number of sexual partners in the preceding 3 months, unprotected sex, optimism or treatment switching). Fully adherent respondents were significantly more likely to feel they were in agreement with their doctor on treatment initiation $\left(x^{2}=6.2 \mathrm{p}=0.045\right)$, the amount of involvement they had in the decision making process $\left(x^{2=} 7.3 \mathrm{p}=.026\right)$, the extent to which their wishes were considered $\left(\mathrm{x}^{2}=12.5 \mathrm{p}=0.002\right)$ and satisfaction with monitoring of their condition $\left(\mathrm{x}^{2}=7.1 \mathrm{p}=0.028\right)$.

Insert table 3 here

\section{Comparisons between adherent and non adherent respondents}

Univarvariate and multivariate analyses were carried out on the data where the groups were divided into fully adherent and the remainder - categorised as "not fully 
adherent". Variables that were found to be significantly (at a 10\% level) associated with full adherence in univariate tests (chi-square and t-tests as appropriate) were age, psychological symptom burden (MSAS-Psych). Patients who were fully adherent to their treatment (mean age $=42.22, \mathrm{sd}=8.3$ ) were older than patients who were not fully adherent $(40.48,8.7)(\mathrm{t}(512)=2.3, \mathrm{p}=0.02)$. Patients who were fully adherent to their treatment reported a lower psychological symptom burden $(1.16, \mathrm{sd}=1.0)$ than patients who were not fully adherent $(1.44,1.0)(\mathrm{t}(522)=-3.3, \mathrm{p}=0.001)$.

For the multivariate analysis, a binary logistic regression with a backward conditional method of entry was carried out to determine the independent predictors for reporting full adherence. Variables in the model that were found to contribute significantly to the model at a $5 \%$ criterion level were Age $(\mathrm{OR}=0.96, \mathrm{p}=0.02)$, Education $(\mathrm{OR}=0.54, \mathrm{p}=0.03)$, Having one sexual partner $(\mathrm{OR}=0.27, \mathrm{p}<0.001)$, having more than one sexual partner $(O R=0.46, p=0.03)$, having risky sex $(O R=4.30, p=$ $0.002)$, being optimistic about treatments $(\mathrm{OR}=0.42, \mathrm{p}=0.01)$, Physical symptoms $(\mathrm{OR}=0.56, \mathrm{p}=0.05)$ and psychological symptoms $(\mathrm{OR}=2.37, \mathrm{p}<0.001)$. The Hosmer-Lemeshow test results $($ Chi-square $=6.8, \mathrm{p}=0.56)$ indicate that the goodness of fit is satisfactory. The Nagelkerke R2 was 0.22 , suggesting that the model has some use in predicting whether people will be fully adherent or not.

\section{Discussion}

We demonstrate the importance of measuring both dose timing and dietary conditions, in addition to measures of simple dose adherence, if a true estimate of overall adherence is to be obtained.

Our data show that on dose adherence, $79.1 \%$ of the group appear adherent, but when all levels of adherence are taken into consideration this figure falls dramatically, to only $41.5 \%$. Non-adherence showed little relationship to demographic, behavioural or attitudinal variables. This concurs with previous studies that were unable to identify any particular at risk groups for non-adherence. Our data shows that HIV patient nonadherence is widespread and not easily predictable on a variety of measures. 
Participants who were fully adherent were older, had lived in the UK for longer and were more likely to be UK born. This would suggest that increased input regarding adherence be directed at younger people and those who are newly arrived in the UK. Length of time in the UK may be a proxy marker for other variables such as familiarity with the health care system, residency, and access to stable accommodation, economic status (which includes access to funds to buy food and other basic necessities) or social isolation. All these factors may affect the ability to adhere to the demands of a difficult regimen. Those who were fully adherent had both lower psychological burden and global symptom index scores. This may either imply that those who are well adjusted and feeling less ill, are more likely to adhere or that enhanced adherence is a trigger for fewer physical symptoms and hence improved psychological functioning. Having one sexual partner may be an indicator of a stable relationship, providing a more supportive environment to enhance and enable adherence. Optimism about treatment, , has been shown in this study to be associated with full adherence. Not surprisingly those who were fully adherent had a significantly higher ranking of their satisfaction with their own ability to adhere. Those who were fully adherent were also significantly more likely to agree with their doctor about treatment commencement, feel involved in the decision making process, feel that their wishes had been considered and feel satisfied with the regular monitoring of their treatment. This data points to the crucial role of good dialogue and interaction between doctor-patient at the time of treatment commencement and throughout ongoing monitoring.

There are some limitations to our data. Our adherence measure relies on self report. Yet none of the other methods can give insight into the levels of adherence we believe are important to measure. The timed electronic caps are prone to potential error, as they may record a missed dose if someone removes a double dose - even if both were taken - and they give no readings of actual consumption of the compound, only if the pill was removed from the container. Doctor reports and estimates are shown to be unreliable. Recall over 7 days provides a partial snapshot and may not be a sensitive enough measure to pick up fluctuations over longer periods of time and changes of the period of treatment The cross sectional nature of the study is also a limitation, offering no longitudinal information or data on causal pathways. However, it does clearly point out associations and thus can direct future studies. . 
This study advances the debate on adherence and highlights the need for a much more rigorous approach to adherence monitoring. Not only should timing and circumstance of adherence be underscored, but also compounds which release patients from such additional adherence obstacles, may assist in reducing the burden of adherence for patients. Clearly the removal of timing and circumstances constraints would mean that dose adherence is the only challenge, which was met by over three quarters of this sample. Newer treatment regimens, with less rigorous adherence demands, may ameliorate the burden of such precise adherence demands. The importance of good relationships and interaction should be incorporated into all treatment management protocols. This requires time, continuity and willingness. A satisfied patient is more likely to adhere. 
Figure 1. Reported adherence for those patients currently on antiretroviral treatment $(n=502)$

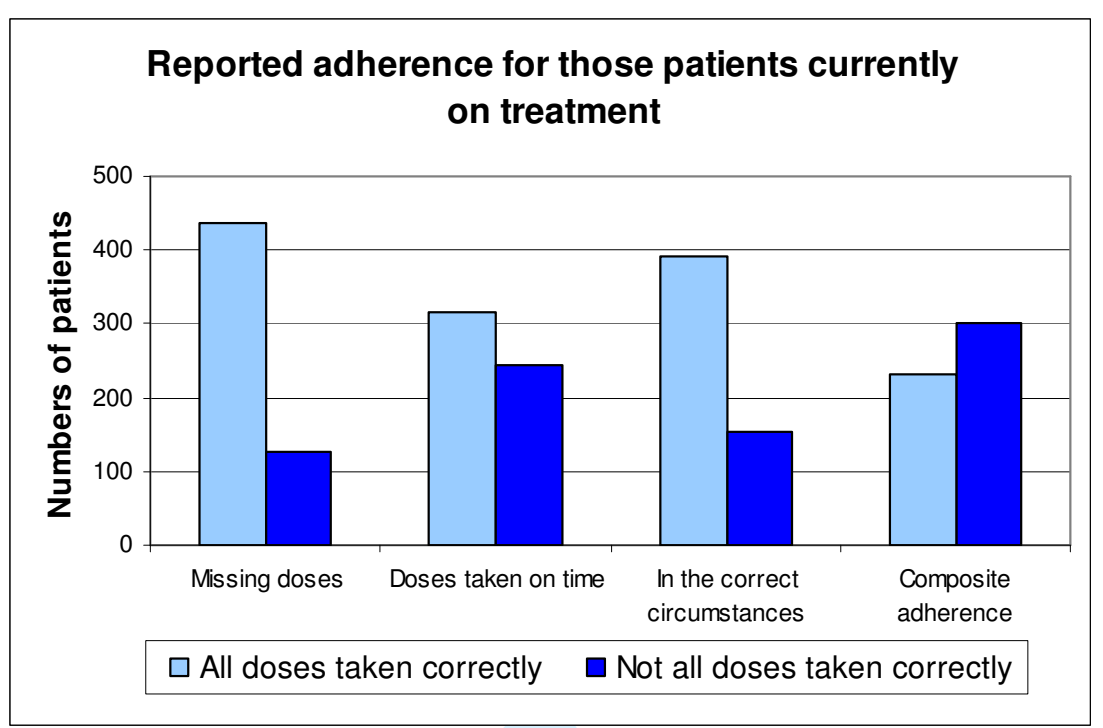


Figure 2 Difference between adherence rates when full or partially measured.

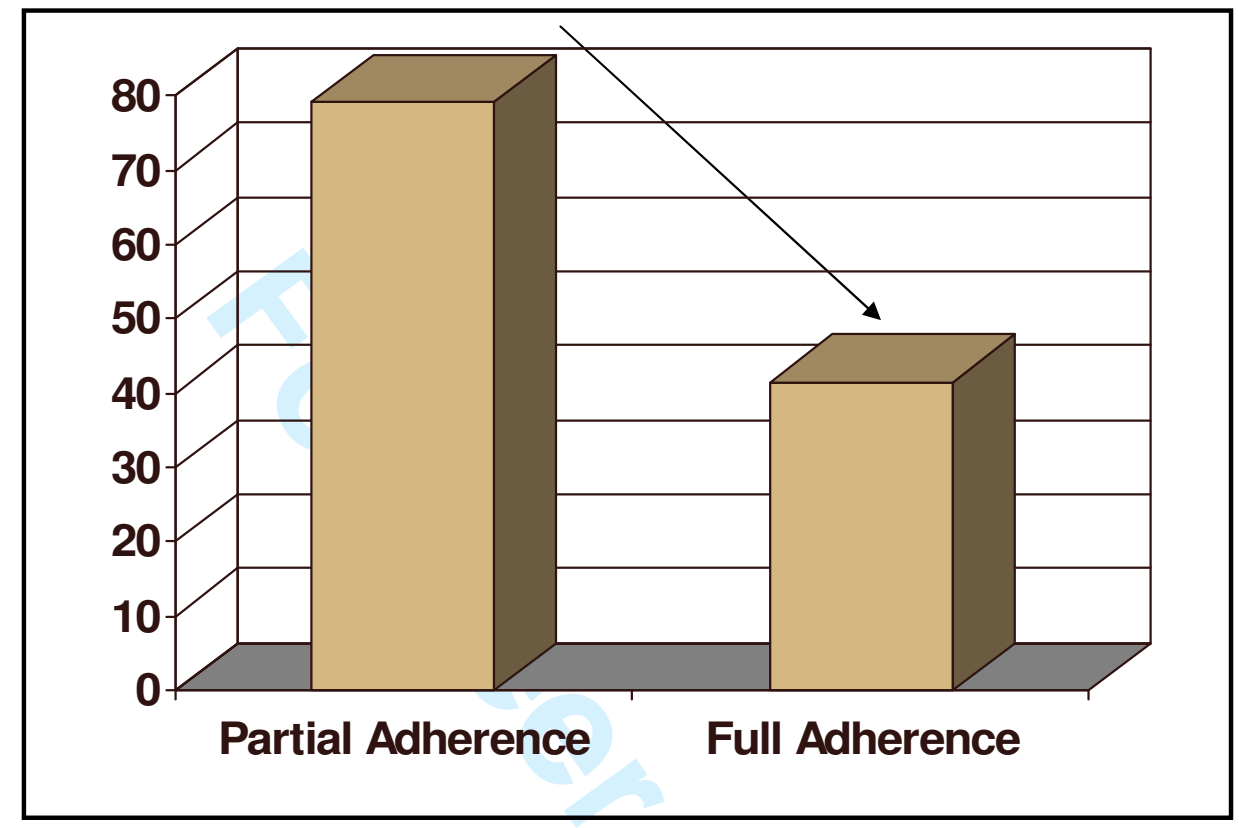


Table 1 - Comparisons between fully adherent, partially adherent and non-adherent respondents on Quality of Life and MSAS Symptoms variables.

\begin{tabular}{|c|c|c|c|c|c|c|c|c|c|}
\hline & \multicolumn{2}{|c|}{ Full Adherent } & \multicolumn{2}{|c|}{$\begin{array}{l}\text { Partial } \\
\text { adherent }\end{array}$} & \multicolumn{2}{|c|}{ Not adherent } & \multicolumn{2}{|c|}{$\begin{array}{l}\text { Statistic } \\
\text { t-test }\end{array}$} & \multirow[b]{2}{*}{ Sig. } \\
\hline & $N$ & $\begin{array}{l}\text { Mean } \\
\text { (sd) }\end{array}$ & $N$ & $\begin{array}{l}\text { Mean } \\
\text { (sd) }\end{array}$ & $N$ & $\begin{array}{l}\text { Mean } \\
\text { (sd) }\end{array}$ & $\mathrm{F}$ & Df & \\
\hline EuroQol & 199 & $\begin{array}{l}0.72 \\
(0.3)\end{array}$ & 170 & $\begin{array}{l}0.69 \\
(0.3)\end{array}$ & 97 & $\begin{array}{l}0.70 \\
(0.2)\end{array}$ & 0.56 & 2 & 0.57 \\
\hline $\begin{array}{l}\text { QOL } \\
\text { general } \\
\text { health }\end{array}$ & 206 & $\begin{array}{l}70.32 \\
(20.7)\end{array}$ & 176 & $\begin{array}{l}66.18 \\
(19.5)\end{array}$ & 100 & $\begin{array}{l}66.69 \\
(20.8)\end{array}$ & 2.27 & 2 & 0.11 \\
\hline MSAS-Phys & 214 & $\begin{array}{l}0.80 \\
(0.7)\end{array}$ & 183 & $\begin{array}{l}0.76 \\
(0.6)\end{array}$ & 105 & $\begin{array}{l}0.91 \\
(0.7)\end{array}$ & 1.78 & 2 & 0.17 \\
\hline MSAS-Psyc & 214 & $\begin{array}{l}1.14 \\
(1.0)\end{array}$ & 183 & $\begin{array}{l}1.38 \\
(0.9)\end{array}$ & 105 & $\begin{array}{l}1.53 \\
(1.1)\end{array}$ & 6.39 & 2 & 0.002 \\
\hline MSAS-GDI & 214 & $\begin{array}{l}1.05 \\
(0.8)\end{array}$ & 183 & $\begin{array}{l}1.16 \\
(0.8)\end{array}$ & 105 & $\begin{array}{l}1.28 \\
(0.8)\end{array}$ & 3.11 & 2 & 0.05 \\
\hline $\begin{array}{l}\text { QOL } \\
\text { before } \\
\text { switch }\end{array}$ & 132 & $\begin{array}{l}3.00 \\
(1.2)\end{array}$ & 103 & $\begin{array}{l}2.65 \\
(1.1)\end{array}$ & 60 & $\begin{array}{l}3.07 \\
(1.3)\end{array}$ & 3.24 & 2 & 0.04 \\
\hline $\begin{array}{l}\text { QL after } \\
\text { switch }\end{array}$ & 130 & $\begin{array}{l}4.08 \\
(0.9)\end{array}$ & 101 & $\begin{array}{l}3.97 \\
(0.9)\end{array}$ & 62 & $\begin{array}{l}3.95 \\
(0.93)\end{array}$ & 0.59 & 2 & 0.56 \\
\hline QOL today & 135 & $\begin{array}{l}4.17 \\
(1.0)\end{array}$ & 102 & $\begin{array}{l}4.02 \\
(1.0)\end{array}$ & 60 & $\begin{array}{l}3.80 \\
(1.0)\end{array}$ & 3.14 & 2 & 0.05 \\
\hline
\end{tabular}


Table 2 Comparisons between fully adherent, partially adherent and non-adherent respondents on demographic, behavioural and attitudinal variables.

\begin{tabular}{|c|c|c|c|c|c|c|c|c|}
\hline VARIABLE & Category & $\mathbf{N}$ & $\begin{array}{c}\text { Full } \\
\text { Adherence }\end{array}$ & $\begin{array}{c}\text { Partial } \\
\text { Adherence }\end{array}$ & $\begin{array}{c}\text { Non } \\
\text { Adherent }\end{array}$ & $\mathrm{X}^{2}$ & Df & sig \\
\hline \multirow[t]{2}{*}{ Gender } & Male & 387 & $43.4 \%$ & $35.7 \%$ & $20.9 \%$ & 0.18 & 2 & 0.91 \\
\hline & Female & 109 & $41.3 \%$ & $37.6 \%$ & $21.1 \%$ & & & \\
\hline \multirow[t]{3}{*}{ Gender/sexuality } & Female & 109 & $41.3 \%$ & $37.6 \%$ & $21.1 \%$ & 0.18 & 4 & 1.00 \\
\hline & Male (het) & 57 & $43.9 \%$ & $35.1 \%$ & $21.1 \%$ & & & \\
\hline & Male (gay) & 326 & $43.3 \%$ & $35.9 \%$ & $20.9 \%$ & & & \\
\hline \multirow{4}{*}{$\begin{array}{l}\text { Country of origin } \\
\text { length of residency } \\
\text { in UK }\end{array}$} & Non-UK & 241 & $37.3 \%$ & $37.8 \%$ & $24.9 \%$ & 6.76 & 2 & 0.03 \\
\hline & UK born & 261 & $47.5 \%$ & $35.2 \%$ & $17.2 \%$ & & & \\
\hline & UK 5+ yrs & 362 & $44.8 \%$ & $37.3 \%$ & $18.0 \%$ & 7.74 & 2 & 0.02 \\
\hline & $\mathrm{UK}<5 \mathrm{yrs}$ & 87 & $34.5 \%$ & $34.5 \%$ & $31.0 \%$ & & & \\
\hline \multirow[t]{2}{*}{ Ethnicity } & White & 335 & $46.0 \%$ & $35.8 \%$ & $18.2 \%$ & 5.33 & 2 & 0.07 \\
\hline & Non-white & 158 & $36.1 \%$ & $38.6 \%$ & $25.3 \%$ & & & \\
\hline \multirow[t]{2}{*}{ Education } & $\begin{array}{c}\text { No } \\
\text { university }\end{array}$ & 270 & $43.3 \%$ & $35.2 \%$ & $21.5 \%$ & 0.27 & 2 & 0.87 \\
\hline & University & 219 & $41.6 \%$ & $7.4 \%$ & $21.0 \%$ & & & \\
\hline \multirow[t]{2}{*}{ Employment } & Employed & 247 & $42.1 \%$ & $36.8 \%$ & $21.1 \%$ & 0.32 & 2 & 0.85 \\
\hline & Not & 217 & $44.7 \%$ & $35.0 \%$ & $20.3 \%$ & & & \\
\hline \multirow[t]{2}{*}{ Disclosure } & No & 30 & $40.0 \%$ & $30.0 \%$ & $30.0 \%$ & 1.65 & 2 & 0.44 \\
\hline & $1+$ & 470 & $42.6 \%$ & $37.0 \%$ & $20.4 \%$ & & & \\
\hline \multirow[t]{2}{*}{ Stable relationship } & No & 195 & $43.1 \%$ & $36.9 \%$ & $20.0 \%$ & 0.001 & 2 & 1.00 \\
\hline & Yes & 269 & $43.1 \%$ & $36.8 \%$ & $20.1 \%$ & & & \\
\hline \multirow[t]{2}{*}{ STI (3/12 months) } & No & 351 & $43.0 \%$ & $36.5 \%$ & $20.5 \%$ & 3.83 & 2 & 0.15 \\
\hline & Yes & 23 & $56.5 \%$ & $39.1 \%$ & $4.3 \%$ & & & \\
\hline \multirow[t]{3}{*}{ Sexual partners $3 / 12$} & None & 121 & $45.5 \%$ & $36.4 \%$ & $18.2 \%$ & & & \\
\hline & One & 165 & $43.6 \%$ & $37.6 \%$ & $18.8 \%$ & 3.29 & 4 & 0.51 \\
\hline & $>$ One & 117 & $36.8 \%$ & $37.6 \%$ & $25.6 \%$ & & & \\
\hline \multirow[t]{2}{*}{ Risky sex } & No & 384 & $43.5 \%$ & $37.5 \%$ & $19.0 \%$ & 0.70 & 2 & 0.70 \\
\hline & Yes & 42 & $47.6 \%$ & $31.0 \%$ & $21.4 \%$ & & & \\
\hline \multirow[t]{2}{*}{$\begin{array}{l}\text { Infectiousness } \\
\text { optimism }\end{array}$} & $\begin{array}{c}\text { Not } \\
\text { optimistic }\end{array}$ & 373 & $43.2 \%$ & $36.2 \%$ & $20.6 \%$ & 0.97 & 2 & 0.62 \\
\hline & Optimistic & 97 & $41.2 \%$ & $41.2 \%$ & $17.5 \%$ & & & \\
\hline \multirow[t]{2}{*}{ Treatment Optimism } & $\begin{array}{c}\text { Not } \\
\text { optimistic }\end{array}$ & 349 & $43.6 \%$ & $35.2 \%$ & $21.2 \%$ & 1.76 & 2 & 0.42 \\
\hline & Optimistic & 110 & $40.9 \%$ & $41.8 \%$ & $17.3 \%$ & & & \\
\hline \multirow[t]{3}{*}{ Treatment switching } & None & 159 & $39.6 \%$ & $40.3 \%$ & $20.1 \%$ & 3.44 & 4 & 0.49 \\
\hline & One & 131 & $48.1 \%$ & $33.6 \%$ & $18.3 \%$ & & & \\
\hline & Multiple & 196 & $41.8 \%$ & $34.7 \%$ & $23.5 \%$ & & & \\
\hline
\end{tabular}


Table 3. Comparison between Fully Partially and non adherent groups on communication and attitudinal variables.

\begin{tabular}{|c|c|c|c|c|}
\hline $\begin{array}{l}\text { Variable } \\
(5 \text { point scale } 1=\text { not at all; } \\
5=\text { very much })\end{array}$ & $\begin{array}{l}\text { Fully } \\
\text { Mean } \\
\text { Rank }\end{array}$ & $\begin{array}{l}\text { Partial } \\
\text { Mean } \\
\text { Rank }\end{array}$ & $\begin{array}{l}\text { Non } \\
\text { Mean } \\
\text { Rank }\end{array}$ & $\begin{array}{l}\text { Statistics } \\
\text { Kruskal-Wallis } \\
\mathrm{X}^{2} \text { significance }\end{array}$ \\
\hline $\begin{array}{l}\text { New drug therapies make HIV people } \\
\text { less infectious }\end{array}$ & 265.57 & 271.13 & 265.10 & $0.19 \mathrm{~ns}$ \\
\hline $\begin{array}{l}\text { Less worried about HIV infection with } \\
\text { improved treatment }\end{array}$ & 251.94 & 272.06 & 255.51 & 2.1 \\
\hline $\begin{array}{l}\text { What extent did patient } \\
\text { play part in decision to start treatment }\end{array}$ & 280.30 & 254.04 & 258.87 & 3.8 \\
\hline $\begin{array}{l}\text { Think Doctor played a part in decision to } \\
\text { start treatment }\end{array}$ & 276.72 & 255.13 & 268.38 & 2.8 \\
\hline $\begin{array}{l}\text { Had adequate information about risks } \\
\text { and benefits of starting treatment }\end{array}$ & 273.32 & 254.05 & 253.85 & 2.4 \\
\hline $\begin{array}{l}\text { Felt they were in agreement with doctor } \\
\text { to start treatment when it happened }\end{array}$ & 276.71 & 249.65 & 249.77 & $\mathrm{p}=0.045$ \\
\hline $\begin{array}{l}\text { Happy with amount of involvement that } \\
\text { they had in the decision making process }\end{array}$ & 281.74 & 251.52 & 251.16 & $\mathrm{p}=0.026$ \\
\hline Satisfied with monitoring of condition & 165.81 & 155.17 & 135.83 & $7.1 \quad \mathrm{p}=.028$ \\
\hline $\begin{array}{l}\text { Satisfied with the extent to which their } \\
\text { wishes were considered }\end{array}$ & 171.60 & 145.78 & 136.28 & $12.5 \mathrm{p}=.002$ \\
\hline Satisfaction with the ability to adhere & 170.53 & 146.06 & 131.10 & $12.2 \mathrm{p}=.002$ \\
\hline
\end{tabular}




\section{REFERENCES}

Aronson JK. Compliance, concordance, adherence.Br J Clin Pharmacol. 2007 Apr;63(4):383-4.

Chang VT, Hwang SS, Kasimis B, Thaler HT. Shorter symptom assessment instruments: the Condensed Memorial Symptom Assessment Scale (CMSAS). Cancer Invest. 2004;22(4):526-36

Chesney M Morin M Sherr L Adherence to HIV combination therapy Soc Sci Med. 2000 Jun;50(11):1599-605

Haynes RB, McDonald H, Garg AX, Montague P. Interventions for helping patients to follow prescriptions for medications. Cochrane Database Syst Rev. 2002;(2):CD000011

Horne R, Buick D, Fisher M, Leake H, Cooper V, Weinman J. Doubts about necessity and concerns about adverse effects: identifying the types of beliefs that are associated with non-adherence to HAART. Int J STD AIDS. 2004 Jan;15(1):38-44.

International Collaboration on HIV Optimism HIV treatments optimism among gay men: an international perspective. J Acquir Immune Defic Syndr. 2003 Apr 15;32(5):545-50

Kalichman SC, DiMarco M, Austin J, Luke W, DiFonzo K. Stress, social support, and HIV-status disclosure to family and friends among HIV-positive men and women. J Behav Med. 2003 Aug;26(4):315-32

Liu H Miller LG, Golin CE Hays RD, Wu T Wenger NS Kaplan AH (2006) Repeated measures analyses of dose timing of antiretroviral medication and its relationship to HIV virologic outcomes Statistics in Medicine

Liu H Miller LG Hays RD Golin CE Wu T Wenger NS Kaplan AH Repeated measures longitudinal analyses of HIV virologic response as a function of percent adherence, dose timing, genotypic sensitivity, and other factors.J Acquir Immune Defic Syndr. 2006 Mar;41(3):315-22.

Lundgren JD, Mocroft A. The impact of antiretroviral therapy on AIDS and survival. J HIV Ther. 2006 Jun;11(2):36-8.

Mems View Users guide (Version 2,61) APREX Intelligent Technology for Medication Managaement Union City CA APrex 1998

Mills EJ, Nachega JB, Buchan I, Orbinski J, Attaran A, Singh S, Rachlis B, Wu P, Cooper C, Thabane L, Wilson K, Guyatt GH, Bangsberg DR. Adherence to antiretroviral therapy in sub-Saharan Africa and North America: a meta-analysis. JAMA. 2006 Aug 9;296(6):679-90.

Paterson DL, Swindells S, Mohr J, Brester M, Vergis EN, Squier C, Wagener MM, Singh N. Adherence to protease inhibitor therapy and outcomes in patients with HIV infection. Ann Intern Med. 2000 Jul 4;133(1):21-30

Poppa A, Davidson O, Deutsch J, Godfrey D, Fisher M, Head S, Horne R, Sherr L; British HIV Association (BHIVA); British Association for Sexual Health and HIV (BASHH). British HIV Association (BHIVA)/British Association for Sexual Health and HIV (BASHH) guidelines on provision of adherence support to individuals receiving antiretroviral therapy (2003). HIV Med. 2004 Jul;5 Suppl 2:46-60

Simoni JM, Pearson CR, Pantalone DW, Marks G, Crepaz N. Efficacy of interventions in improving highly active antiretroviral therapy adherence and HIV-1 RNA viral load. A meta-analytic review of randomized controlled trials. J Acquir Immune Defic Syndr. 2006 Dec 1;43 Suppl 1:S23-35

Sherr L, Adherence--sticking to the evidence. AIDS Care. 2000 Aug;12(4):373-5 
The EuroQol Group (1990) EuroQol-a new facility for the measurement of health-related quality of life. The EuroQol Group. Health Policy 16:199-208

van Dulmen S, Sluijs E, van Dijk L, de Ridder D, Heerdink R, Bensing J. Patient adherence to medical treatment: a review of reviews. BMC Health Serv Res. 2007 Apr 17;7:55 